\title{
Manajemen proyek Sistem Informasi Penggajian Berbasis Web
}

\author{
Edi Setiawan
}

Jurusan Teknik Informatika, Fakultas Teknik, Universitas Negeri Gorontalo e-mail: edisetiawan@ung.ac.id

\begin{abstract}
Abstrak
Manajemen proyek merupakan strategi yang perlu dilakukan dalam mencapai efisiensi dan efektifitas suatu perusahaan. Perkembangan pada era teknologi masa ini sejalan dengan berkembangnya UKM yang bergerak di bidang jasa penggajian kerajinan karawo, seperti Rumah Karawo. Perencanaan proyek tersebut dapat disusun menggunakan Work Breakdown Structure (WBS).Manajemen proyek dapat pula digunakan untuk memperkirakan adanya percepatan proyek (crasing) pada Rumah Karawo. Dengan penyusunan suatu manajemen proyek yang baik, maka dapat dilakukan estimasi waktu dan biaya yang diperlukan dalam menjalankan proyek, sehingga dapat meminimasi kerugian biaya akibat kemungkinan keterlambaran proyek. Pengembangan perencanaan manajemen proyek yang dilakukan mengunakan waterfall.
\end{abstract}

Kata kunci: Manajemen Proyek, WBS, Crasing, waterfall

\begin{abstract}
Project management is a strategy that needs to be done in achieving the efficiency and effectiveness of a company. Developments in the era of technology in this period are in line with the development of SMEs engaged in the field of karawo craft services, such as Rumah Karawo. The project planning can be prepared using Work Breakdown Structure (WBS). Project management can also be used to estimate the project acceleration (crasing) at Karawo House. With the preparation of a good project management, it can be estimated the time and cost needed to run the project, so as to minimize cost losses due to the possibility of project overturning. The development of a project management plan carried out using a waterfall.
\end{abstract}

Keywords: Project Management, WBS, Crasing, waterfall

\section{Pendahuluan}

Perkembangan teknologi informasi saat ini dapat mempengaruhi efektivitas operasional pada perusahaan/ organisasi. Raymond Mcleod. JR. (2008) dalam bukunya "Sistem Informasi Manajemen merupakan suatu sistem berbasis komputer yang membuat informasi tersedia bagi para pengguna yang memiliki kebutuhan serupa". Sebuah teknologi informasi yang diterapkan dimanfaatkan sebagai salah satu solusi untuk meminimalisir tingkat kesalahan pada pengguna, baik pelayanan kepada karyawan maupun dalam memanajemen penggajian dan data kepada sesama karyawan perusahaan.

Dampak penerapan teknologi informasi yang semakin pesat ini sudah merambah kepada semua bidang, tak terkecuali pada aspek-aspek Usaha Menengah dalam bidang jasa dan kerajinan Karawo di Rumah Karawo di gorontalo. Salah satu teknologi yang diterapkan di Rumah Karawo adalah sistem penggajian. Seperti perusahaan jasa 
lainnya yang menyediakan suatu program aplikasi sistem informasi dengan tujuan untuk membantu serta memudahkan pengelolaan proses penggajian dan kebijakankebijakan lainnya yang bersifat strategis. Menurut definisi dalam buku panduan PMBOK (A Guide to the Project Management Body of Knowledge) pada Heryanto (2015), definisi proyek adalah suatu usaha sementara yang dilaksanakan untuk menghasilkan suatu produk atau jasa yang unik.

Proyek yang dilaksanakan secara temporer tentu perlu diatur dan dikendalikan dengan baik. Untuk melakukan pengaturan dan pengendalian diperlukan kaidahkaidah yang menjadi pedoman untuk pelaksanaannya. "Manajemen proyek adalah aplikasi dari pengetahuan, keahlian, alat dan teknik untuk melaksanakan aktivitas sesuai dengan kebutuhan proyek" (Tantra, 2012).

Tujuan utama dari manajemen proyek adalah agar proyek dapat dilaksanakan dengan efisien, tepat waktu, dan mencapai hasil yang diinginkan. Sering terjadi pada sebuah proyek yang berlarut pada pekerjaannya sehingga pada akhirnya harus mengalami penjadwalan ulang. Oleh karena itu, peran perencanaan dalam suatu proyek sangat penting, segala sesuatu harus dimulai dari rencana dan harus disepakati bersama antara para stakeholder yang terlibat pada proyek. Stakeholder yang dimaksud didalam proyek adalah pemilik proyek (project owner), komite pengarah (steering committee), pengguna hasil proyek dan pelaksana proyek (Heryanto, 2015).

Project Management Conceptual Framework merupaka Konsep Pekerjaan yang meliputi seluruh fase kegiatan pada permulaan hingga proses penyelesaian akhir proyek yang saling mempengaruhi antar satu fase dengan fase lainnya.

Model waterfall sering juga disebut model sekuensial linier (sequential linier) atau alur hidup klasik (classic life cycle). Model ini menyediakan pendekatan alur hidup perangkat lunak secara sekuensial atau terurut dimulai dari analisis, desain, pengkodean, pengujian dan tahap pendukung pembuatan sisitem.

Selain itu berdasarkan hasil penelitian dari Liliana dalam Sistem Informasi Manajemen Proyek Instalasi Air dalam penelitian ini membahas Ketika proyek direkam secara konvensional, menggunakan kertas atau file komputer secara mandiri, seringkali menyebabkan masalah dalam hal ruang pencarian dan penyimpanan data. Selain itu, ketika perusahaan menangani lebih dari satu proyek, itu dapat menyebabkan miskomunikasi, kehilangan data, kesalahan perhitungan, dan sebagainya. Untuk mengatasi masalah tersebut, dibutuhkan sistem informasi berbasis komputer yang dapat diakses oleh semua pihak, yang dapat membantu proses bisnis perusahaan. Penelitian ini dilakukan dengan menggunakan SDLC. Berdasarkan hasil 
pengujian menunjukkan bahwa integrasi antara semua departemen membuat pemantauan yang lebih baik dari pengembangan proyek, rekaman komunikasi yang lebih baik antara perusahaan dan klien, manajemen stok yang lebih baik, dan pada akhirnya, dapat meningkatkan laba perusahaan.

\section{Metode}

Metode yang dilakukan yaitu mulai dari penemuan masalah, penentuan tujuan penelitian, pengumpulan dan pengolahan data. Tahap yang dilakukan untuk pengolahan data adalah:

- Identifikasi aktivitas proyek dengan menggunakan Work Breakdown Structure (WBS) sederhana.

- pembuatan sistem sesusai dengan model pengembangan sistem waterfall (pekerjaan system yang terurut) (pressman 2010)

Work breakdown structure (WBS) merupakan suatu pengelompokkan elemen kerja yang ditunjukkan dalam bentuk grafik untuk mengatur dan membagi keseluruhan ruang lingkup suatu proyek kerja (Rev, 2003).

\section{Analisa Sistem Berjalan}

Untuk menjabarkan sistem yang berjalan pada kegiatan proyek, penulis mencoba menggambarkan melalui metode Conceptual Framework yang meliputi seluruh proses kegiatan proyek. Work Breakdown Structure (WBS) dan software Microsoft Project untuk merancang penjadwalan proyek dan estimasi biaya.

\begin{tabular}{|l|l|}
\hline \multirow{5}{*}{ a. Project Organisation } & $\begin{array}{l}\text { Mendeskripsikan kebutuhan pengorganisasian pada } \\
\text { manajemen proyek secara keseluruhan, meliputi : } \\
\text { perencanaan, penjadwalan, prosedur pendaftaran } \\
\text { dan pengajuan proyek pada fase pelelangan. } \\
\text { Penyusunan berkas-berkas pendukung seperti : } \\
\text { RAB (Rencana Anggaran Biaya), perpajakan, izin } \\
\text { usaha, kontrak kerja dan dokumen-dokumen } \\
\text { pendukung lainnya }\end{array}$ \\
\hline b. Scope & $\begin{array}{l}\text { Pada fase ini proyek telah mulai dilaksanakan, } \\
\text { partisipasi dari rekan dan relasi yang terkait didalam } \\
\text { kontrak kerja harus diidentifikasi secara detail. }\end{array}$ \\
\hline \multirow{5}{*}{ Clanning } & $\begin{array}{l}\text { Tahap perencanaan mendefinisikan spesifikasi } \\
\text { pekerjaan yang akan dilaksanakan, meliputi : } \\
\text { penganggaran serta realisasi RAB (Rencana } \\
\text { Anggaran Biaya) yang telah disetujui. }\end{array}$ \\
\hline
\end{tabular}




\begin{tabular}{|l|l|}
\hline \multirow{2}{*}{$\begin{array}{l}\text { d. Risk Management } \\
\text { e. Progress and } \\
\text { Performance. }\end{array}$} & $\begin{array}{l}\text { Pada fase ini, pimpinan menekankan fokus kegiatan } \\
\text { pada kebijakan-kebijakan pengawasan terkait } \\
\text { pelaksanaan kegiatan proyek yang sedang } \\
\text { berlangsung. }\end{array}$ \\
\hline \multirow{2}{*}{$\begin{array}{l}\text { Auditing, Documentation } \\
\text { and Closing }\end{array}$} & $\begin{array}{l}\text { Fase ini merupakan bentuk kemajuan dan realisasi } \\
\text { yang telah terlaksana pada seluruh kegiatan proyek } \\
\text { yang sedang berjalan. }\end{array}$ \\
& $\begin{array}{l}\text { Laporan akhir kegiatan proyek, pemberkasan dan } \\
\text { lokumen serta dokumentasi yang dilaksanakan di } \\
\text { dipertanggungjawabkan kepada pihak stakeholder } \\
\text { (Rumah Karawo). }\end{array}$ \\
\hline
\end{tabular}

Roger S. Pressman memecah model ini menjadi 6 tahapan meskipun secara garis besar sama dengan tahapan-tahapan model waterfall pada umumnya. Berikut adalah Gambar dan penjelasan dari tahap-tahap yang dilakukan di dalam model ini menurut Pressman:

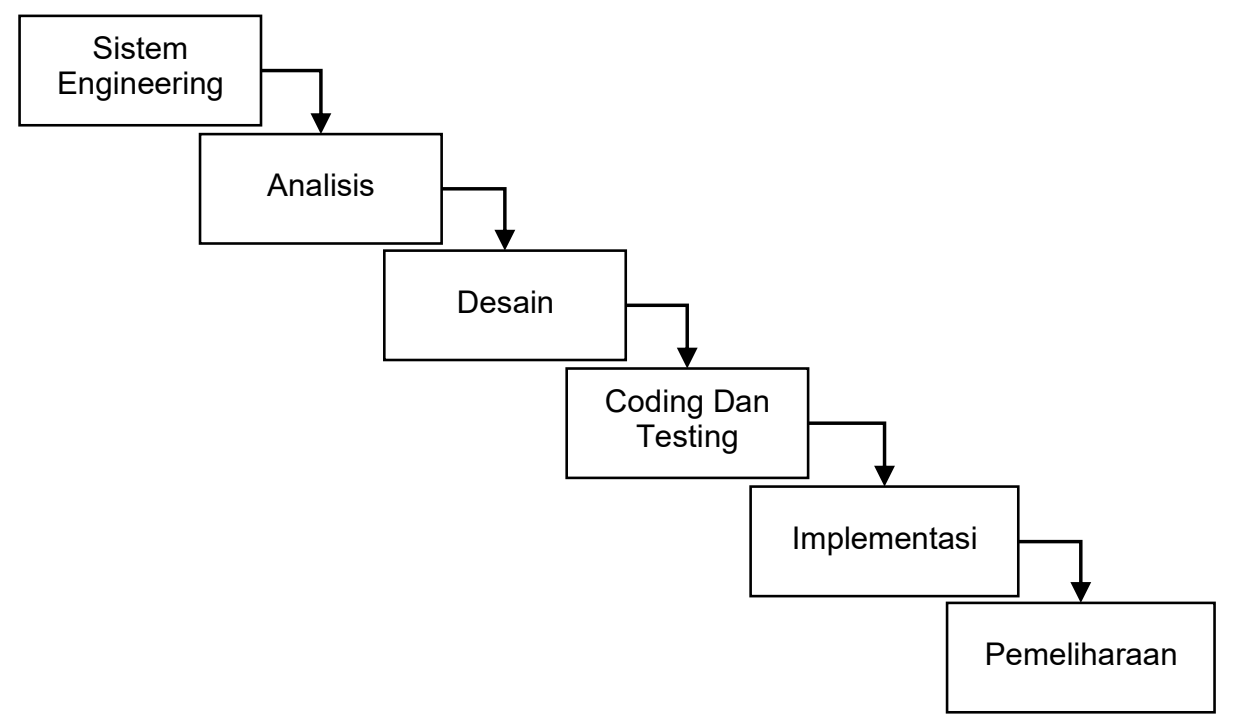

Gambar1. Metode Waterfall menurut Pressman

a. System / Information Engineering and Modeling. Permodelan ini diawali dengan mencari kebutuhan dari keseluruhan sistem yang akan diaplikasikan ke dalam bentuk software. Hal ini sangat penting, mengingat software harus dapat berinteraksi dengan elemen-elemen yang lain seperti hardware, database, dsb. Tahap ini sering disebut dengan Project Definition.

b. Software Requirements Analysis. 
Proses pencarian kebutuhan diintensifkan dan difokuskan pada software. Untuk mengetahui sifat dari program yang akan dibuat, maka para software engineer harus mengerti tentang domain informasi dari software, misalnya fungsi yang dibutuhkan, user interface, dsb. Dari 2 aktivitas tersebut (pencarian kebutuhan sistem dan software) harus didokumentasikan dan ditunjukkan kepada pelanggan.

c. Design.

Proses ini digunakan untuk mengubah kebutuhan - kebutuhan diatas menjadi representasi ke dalam bentuk "blueprint" software sebelum coding dimulai. Desain harus dapat mengimplementasikan kebutuhan yang telah disebutkan pada tahap sebelumnya. Seperti 2 aktivitas sebelumnya, maka proses ini juga harus didokumentasikan sebagai konfigurasi dari software.

d. Coding.

Untuk dapat dimengerti oleh mesin, dalam hal ini adalah komputer, maka desain tadi harus diubah bentuknya menjadi bentuk yang dapat dimengerti oleh mesin, yaitu ke dalam bahasa pemrograman melalui proses coding. Tahap ini merupakan implementasi dari tahap design yang secara teknis nantinya dikerjakan oleh programmer.

e. Testing / Verification.

Sesuatu yang dibuat haruslah diujicobakan. Demikian juga dengan software. Semua fungsi-fungsi software harus diujicobakan, agar software bebas dari error, dan hasilnya harus benar-benar sesuai dengan kebutuhan yang sudah didefinisikan sebelumnya.

f. Maintenance.

Pemeliharaan suatu software diperlukan, termasuk di dalamnya adalah pengembangan, karena software yang dibuat tidak selamanya hanya seperti itu. Ketika dijalankan mungkin saja masih ada errors kecil yang tidak ditemukan sebelumnya, atau ada penambahan fitur-fitur yang belum ada pada software tersebut. Pengembangan diperlukan ketika adanya perubahan dari eksternal perusahaan seperti ketika ada pergantian sistem operasi, atau perangkat lainnya.

\section{Hasil dan Pembahasan}

\section{Identifikasi Aktivitas Proyek}

pada Gambar 2. Alur diagram yang menunjukkan urutan. Dalam melakukan perencanaan manajemen proyek yang baik perlu diawali dengan melakukan identifikasi aktivitas-aktivitas yang dilakukan. Menurut Duncan (1996), ruang lingkup aktivitas-aktivitas yang akan dilakukan dalam suatu proyek dapat digambarkan dalam 
suatu Work Breakdown Structure (WBS) sederhana sehingga didapatkan informasi yang merinci mengenai proyek sistem yang dibuat.

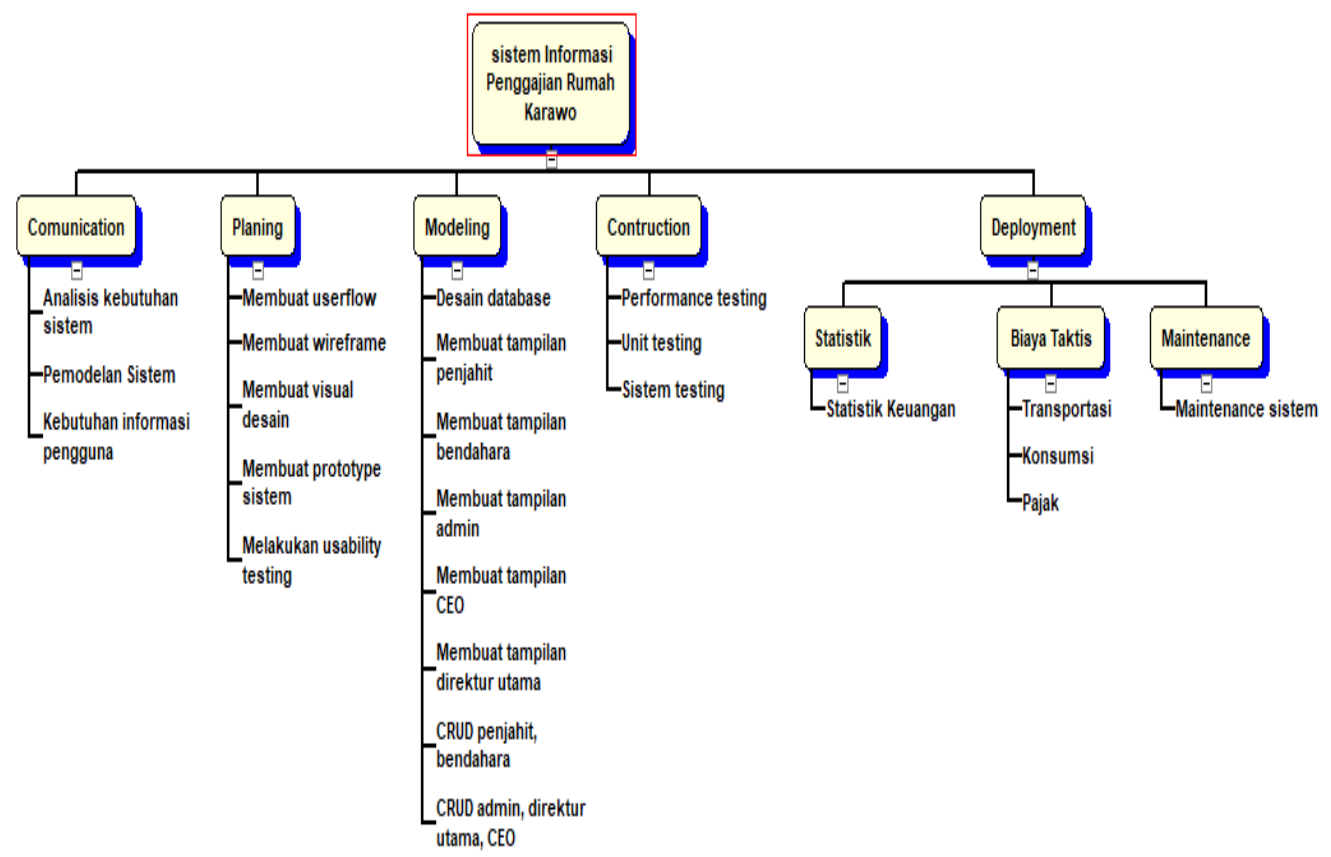

Gambar 2. Work Breakdown Structure

Perencanaan Aktivitas Global

Perencanaan aktivitas global dilakukan dengan pengalokasian sumber daya manusia yang professional untuk menduduki posisis proyek yang ditentukan, biaya, dan waktu yang dibutuhkan. Seperti pada Tabel 1 dapat diketahui pekerja-pekerja yang bertanggung jawab dalam pelaksanaan tiap aktivitas sehingga memudahkan dalam melakukan monitoring proyek. Alur aktivitas yang dilakukan tergambarkan dalam presedence diagram yang tercantum gambar 1 .

Tabel 1. Alokasi SDM untuk Aktivitas Proyek

\begin{tabular}{|c|c|c|c|c|c|c|c|}
\hline & WBS & Name & Duration & Start & Finish & Cost & Work \\
\hline 1 & 1 & $\square$ sistem Informasi Penggajian Rumah K & 380d & 10/5/2019 & $12 / 21 / 2020$ & Rp9,360,00 & 150h \\
\hline 2 & 1.1 & $\boxminus$ Comunication & $0.38 \mathrm{~d}$ & 10/5/2019 & 10/5/2019 & Rp640,000 & $8 \mathbf{h}$ \\
\hline 3 & 1.1 .1 & Analisis kebutuhan sistem & $0.38 \mathrm{~d}$ & $10 / 5 / 2019$ & $10 / 5 / 2019$ & Rp240,000 & $3 \mathrm{~h}$ \\
\hline 4 & 1.1 .2 & Pemodelan Sistem & $0.38 \mathrm{~d}$ & $10 / 5 / 2019$ & $10 / 5 / 2019$ & Rp240,000 & $3 \mathrm{~h}$ \\
\hline 5 & 1.1 .3 & Kebutuhan informasi pengguna & $0.25 d$ & $10 / 5 / 2019$ & $10 / 5 / 2019$ & Rp160,000 & $2 \mathrm{~h}$ \\
\hline 6 & 1.2 & $\boxminus$ Planing & 2.5d & 10/7/2019 & 10/9/2019 & Rp640,000 & 24h \\
\hline 7 & 1.2 .1 & Membuat userflow & $0.5 \mathrm{~d}$ & $10 / 7 / 2019$ & $10 / 7 / 2019$ & Rp106,667 & $4 \mathrm{~h}$ \\
\hline 8 & 1.2 .2 & Membuat wireframe & $0.5 \mathrm{~d}$ & $10 / 7 / 2019$ & $10 / 7 / 2019$ & Rp106,667 & $4 \mathrm{~h}$ \\
\hline 9 & 1.2 .3 & Membuat visual desain & 1d & $10 / 8 / 2019$ & 10/8/2019 & Rp213,333 & $8 \mathrm{~h}$ \\
\hline 10 & 1.2 .4 & Membuat prototype sistem & $0.5 \mathrm{~d}$ & $10 / 9 / 2019$ & $10 / 9 / 2019$ & Rp106,667 & $4 \mathrm{~h}$ \\
\hline 11 & 1.2 .5 & Melakukan usability testing & $0.5 d$ & 10/9/2019 & 10/9/2019 & Rp106,667 & $4 \mathrm{~h}$ \\
\hline 12 & 1.3 & $\boxminus$ Modeling & 9d & $10 / 10 / 2019$ & $10 / 19 / 2019$ & Rp2,560,00 & $72 \mathrm{~h}$ \\
\hline 13 & 1.3 .1 & Desain database & $1 d$ & $10 / 10 / 2019$ & $10 / 10 / 2019$ & Rp284,445 & $8 \mathrm{~h}$ \\
\hline 14 & 1.3 .2 & Membuat tampilan penjahit & $0.5 \mathrm{~d}$ & $10 / 11 / 2019$ & 10/11/2019 & Rp142,222 & $4 \mathrm{~h}$ \\
\hline 15 & 1.3 .3 & Membuat tampilan bendahara & $0.5 \mathrm{~d}$ & 10/11/2019 & 10/11/2019 & Rp142,222 & $4 \mathrm{~h}$ \\
\hline 16 & 1.3 .4 & Membuat tampilan admin & $0.5 \mathrm{~d}$ & $10 / 12 / 2019$ & $10 / 12 / 2019$ & Rp142,222 & $4 \mathrm{~h}$ \\
\hline 17 & 1.3 .5 & Membuat tampilan CEO & $0.5 \mathrm{~d}$ & $10 / 12 / 2019$ & $10 / 12 / 2019$ & Rp142,222 & $4 \mathrm{~h}$ \\
\hline 18 & 1.3 .6 & Membuat tampilan direktur utama & $0.5 \mathrm{~d}$ & $10 / 14 / 2019$ & $10 / 14 / 2019$ & Rp142,222 & $4 \mathrm{~h}$ \\
\hline 19 & 1.3 .7 & CRUD penjahit, bendahara & $2.5 \mathrm{~d}$ & $10 / 14 / 2019$ & $10 / 16 / 2019$ & Rp711,111 & $20 \mathrm{~h}$ \\
\hline 20 & 1.3 .8 & CRUD admin, direktur utama, CEO & $3 d$ & $10 / 17 / 2019$ & 10/19/2019 & Rp853,333 & $24 \mathrm{~h}$ \\
\hline \multirow{2}{*}{$\mathrm{Scl}$} & & truction & $0.38 d$ & 10/21/2019 & 10/21/2019 & Rp320,000 & $\mathbf{8 h}$ \\
\hline & & Berformanre tectinn & $02 a^{4}$ & $10 / 21 / 2 n 19$ & $1 n / 21 / 2 n 19$ & RnRn กnก & $2 \mathrm{~h}$ \\
\hline
\end{tabular}




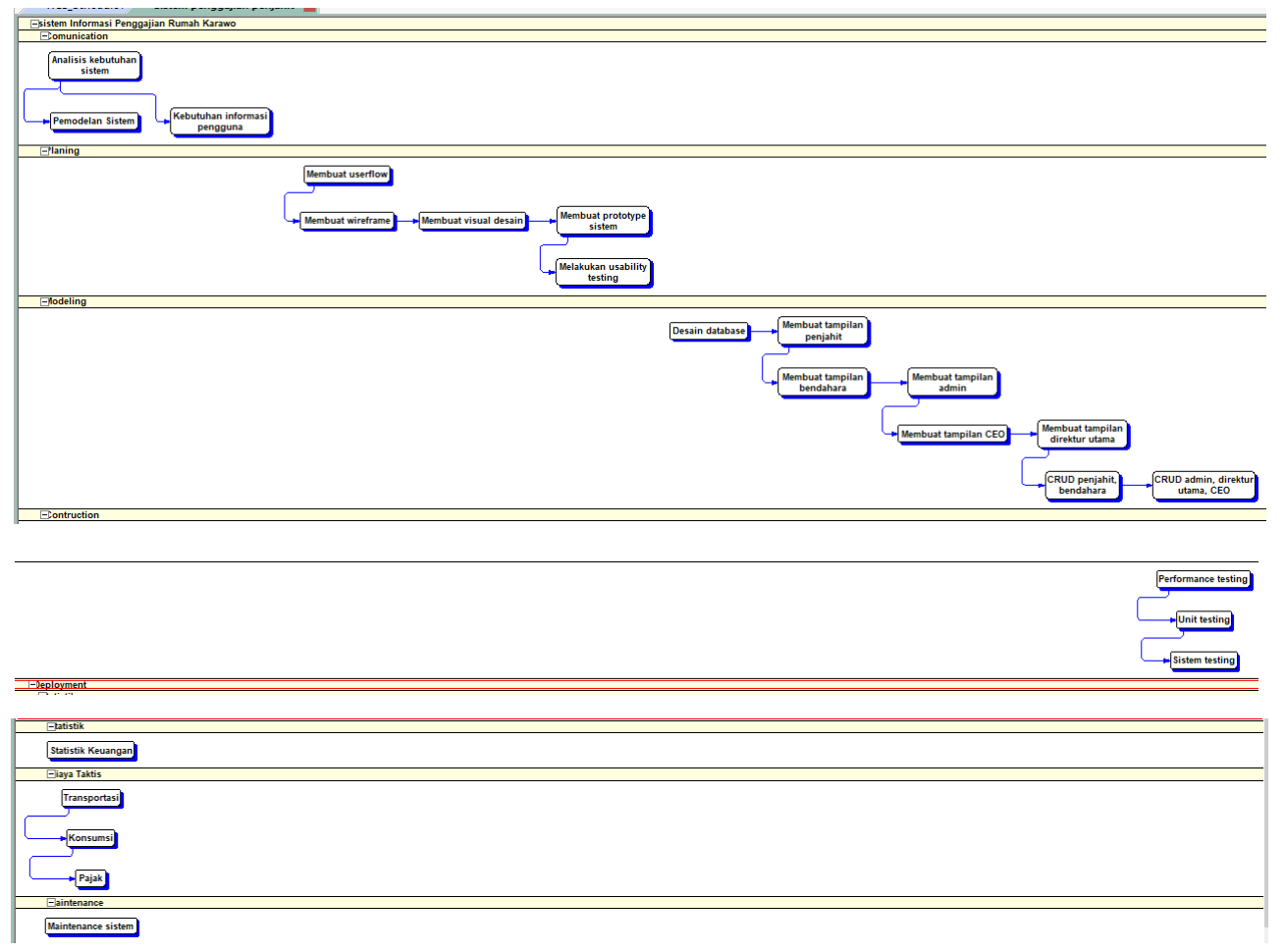

Gambar 3. Alur pekerjaan

Pengestimasian Biaya Proyek yang Dipercepat (Crashing) Dalam pelaksanaan proyek Hanya dapat dilakukan pengestimasian waktu proyek yang lebih cepat dari waktu normalnya. Dalam hal ini disebut sebagai crash time. Pada Gambar 4 menunjukkan jumlah hari dan biaya untuk aktivitas dengan crash time. Biaya crash cenderung lebih tinggi dibanding biaya nornal karena jumlah hari pelaksanaan aktivitas yang lebih cepat memerlukan penambahan pekerja yaitu seorang desainer dan seorang programmer, bisa dilihat di Gambar 3. 


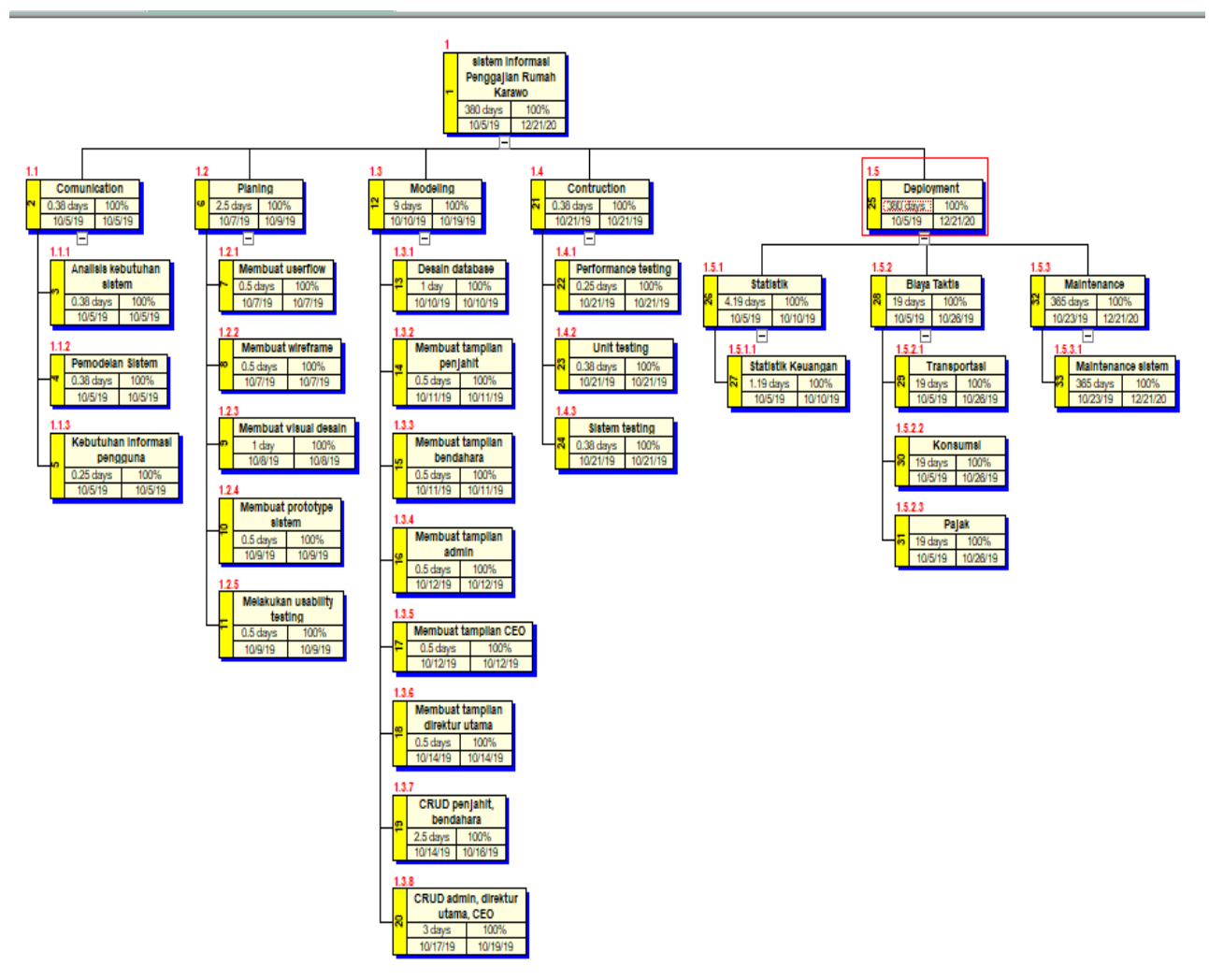

Gambar 4. crash time

Analisis Project Crashing Dalam melaksanakan proyek Hanya dapat dilakukan percepatan aktivitas proyek (Crashing) tetapi dengan adanya trade off antara waktu dan biaya. Percepatan yang dapat dilakukan dengan mengurangi jumlah aktivitas sebanyak 3 hari, yaitu pada aktivitas proyek normal dilakukan selama 21 hari menjadi 18 hari. Percepatan tersebut dapat dilakukan dengan cara menambah jumlah pekerja, yaitu seorang desainer dan seorang programmer. Sehingga, total biaya crashing meningkat akibat adanya penambahan biaya langsung. Trade off ini yang dapat disampaikan Rumah Karawo pada client dimana client yang dapat menentukan untuk memilih pengerjaan proyek yang lebih cepat dengan biaya yang lebih tinggi atau proyek yang lebih lama dengan biaya yang lebih rendah.

\section{Analisa Kebutuhan Sistem Berjalan}

Kebutuhan data dan informasi yang dibutuhkan digambarkan melalui diagram use case sistem berjalan. 


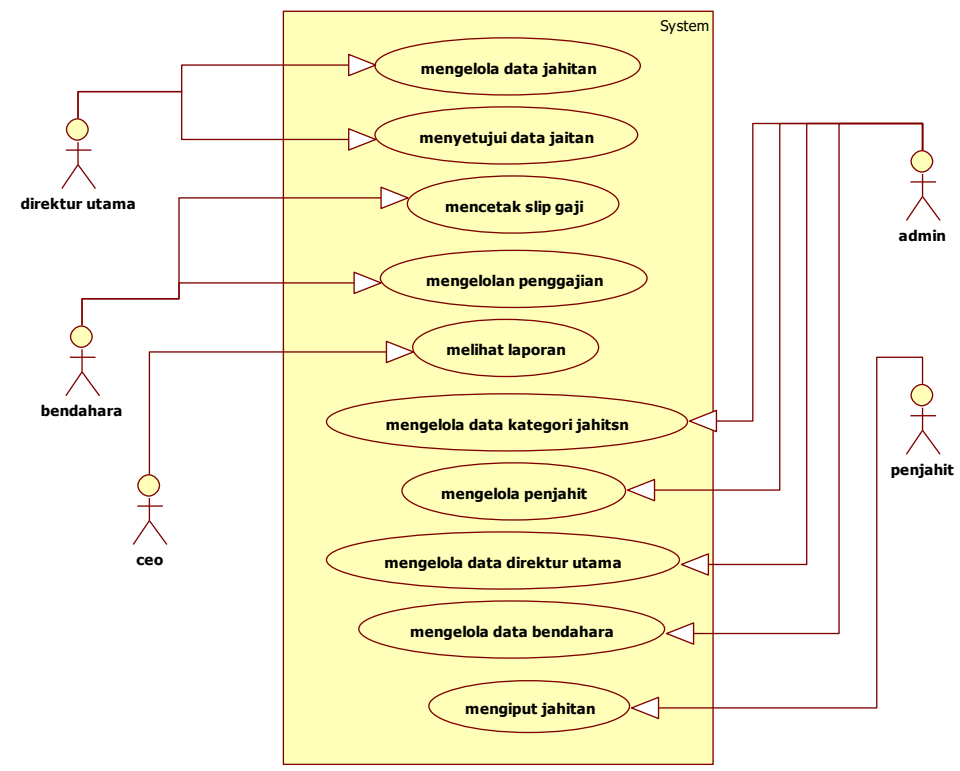

Gambar 5. Use Case Sistem Berjalan

\section{Rancangan Antar Muka}

Implementasi antarmuka susunan kegiatan proyek ditunjukkan pada contoh tampilan Gambar 4. Antarmuka susunan kegiatan sistem penggajian merupakan halaman yang ditampilkan setelah admin memilih menu yang terdapat pada aplikasi. Pada halaman ini terdapat informasi mengenai semua kegiatan user yang terlibat di Rumah Karawo

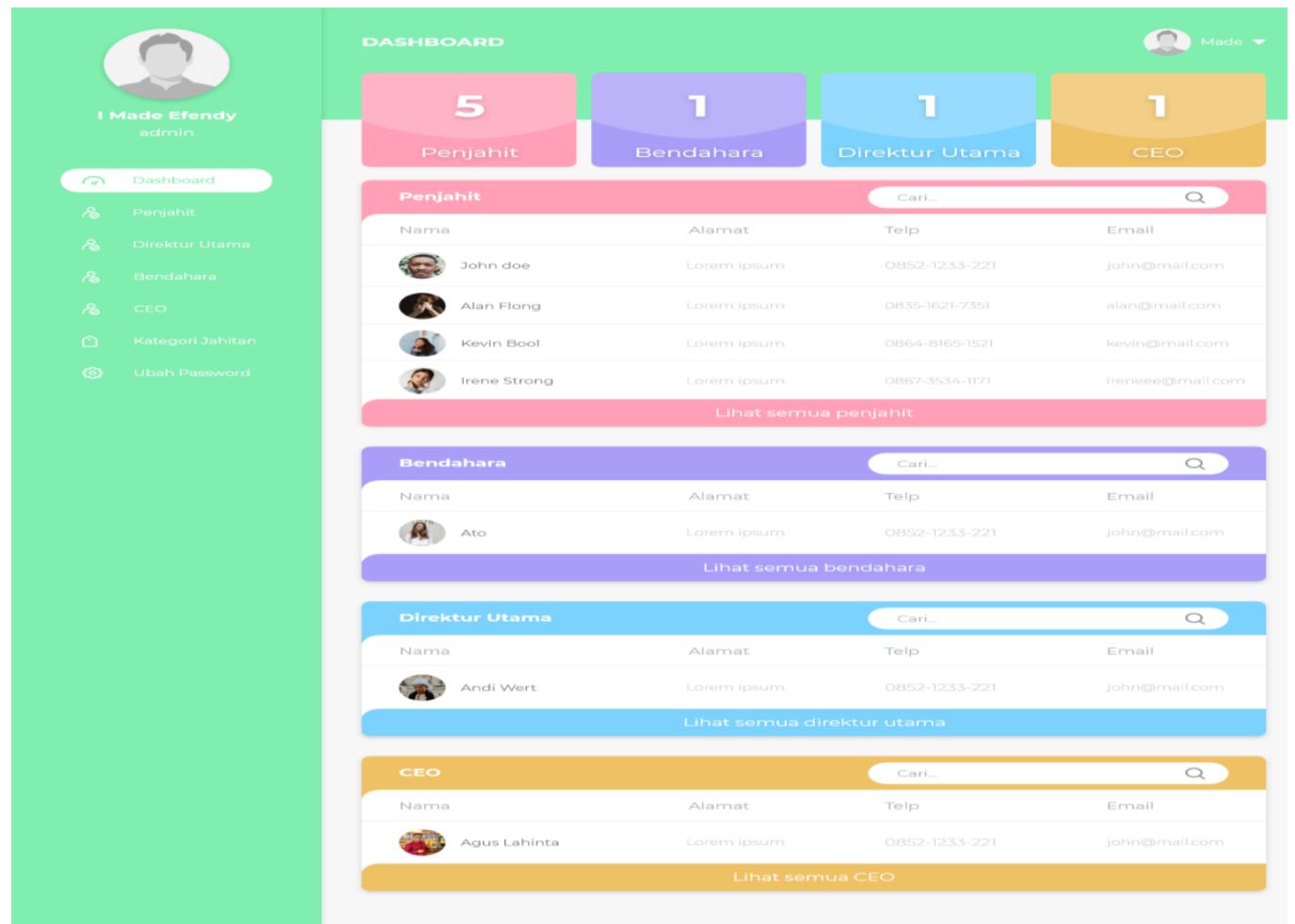

Gambar 6. halaman admin 
Contoh Gambar 5 merupakan halaman awal untuk admin. Di sini admin dapat melihat jumlah pengguna aplikasi serta perkembangan data pengguna.

\section{Kesimpulan}

Kegiatan dan pelaksanaan proyek terdiri dari bermacam proses dan prosedur yang harus diselenggarakan bersama antara pihak manajemen Rumah Karawo, konsultan dan stakeholder selaku pemegang modal Pemanfaatan sistem informasi pada manajemen proyek perlu dilakukan untuk memberikan berbagai kemudahan pada pelaksanaan proyek yang dijalankan. Rancangan ini memberikan solusi melalui metode Waterfall yang didasarkan pada kebutuhan perusahaan pada pengolahan data dan informasi terkait pada prosedur dan pelaksanaan teknis pekerjaan.

Mengingat kebutuhan sarana dan prasarana yang cukup kompleks pada pelaksanaan kegiatan proyek, perlu difasilitasi kesiapan infrastruktur yang optimal, baik dari segi sumber daya manusia, peralatan dan perlengkapan serta sistem informasi yang mampu merangkul keseluruhan prosedur yang dibutuhkan oleh semua pihak yang terkait

\section{Daftar Pustaka}

Duncan, W. R. (1996). A Guide to The Project Management Body of Knowledge. Sylva: PMI Communication

Heryanto, Imam dan Totok Triwibowo. 2015. Manajemen Proyek Berbasis Teknologi Informasi : Mengelola Proyek Secara Sistematis Menggunakan Microsoft Project. Bandung : Informatika.

Liliana (2014). Sistem Informasi Manajemen Proyek Instalasi Air. SNASTIA 2014, ISSN 1979-3960

McLeod, Jr dan George P. Schell. 2008. Sistem Informasi Manajemen. Jakarta : Salemba Empat.

Rudy Tantra (2012). Manajemen Proyek Sistem Informasi, Bagaimana Mengelola Proyek Sistem Informasi Secara Efektif Dan Efisien,Andi Publiser. ISBN: 978979-29-3095-5

Rev, E. (2003). Work Breakdown Structure. America: U.S. Department of Energy. 